\title{
THE LETTERS OF
}

Charles and Mary Anne Lamb

Volume I • Letters of Charles Lamb • 1796-1801 
ALSO EDITED BY EDWIN W. MARRS, JR.

The Letters of Thomas Carlyle to His Brother Alexander, with Related Family Letters, 1968 


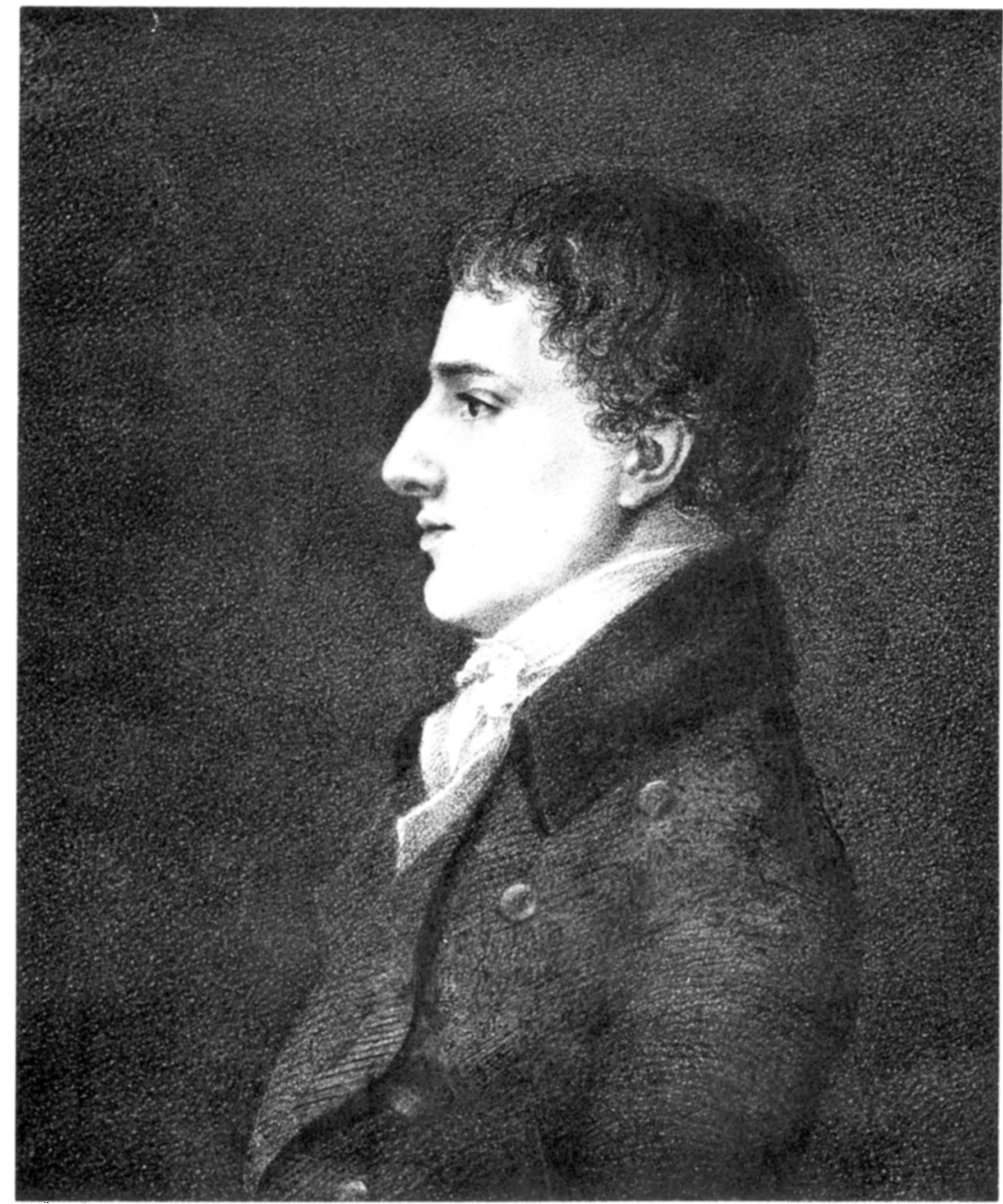

Gharles Lamb at twenty-three.

From a pencil and chalk drawing by Robert Hancock (1730-1817). Courtesy of the National Portrait Gallery, London. 


\title{
THE LETTERS OF \\ Charles and Mary Anne Lamb
}

\author{
Volume I • Letters of Charles Lamb • I 796-18o I
}

EDITED by EDWIN W. MARRS, JR.

CORNELL UNIVERSITY PRESS

ITHACA AND LONDON

1975 


\section{Copyright (c) 1975 by Cornell University}

All rights reserved. Except for brief quotations in a review, this book, or parts thereof, must not be reproduced in any form without permission in writing from the publisher. For information address Cornell University Press, 124 Roberts Place, Ithaca, New York 14850.

First published 1975 by Cornell University Press.

Published in the United Kingdom by Cornell University Press Ltd., 2-4 Brook Street, London W1Y IAA

International Standard Book Number 0-8014-0930-6

Library of Congress Catalog Card Number 75-8436 
To

\section{Perthenia Northcraft Marrs} and our daughters

Nancy, Lisa, and Jenny 